\title{
Peningkatan Kualitas Produk Melalui Implementasi Teknologi Kreatif Usaha Tauge
}

\author{
Zachari Abdallah ${ }^{1}$, Poni Yunita ${ }^{1}$, Ayu Esteka Sari ${ }^{1}$, Maryanto \\ STIE Sakti Alam Kerinci \\ zachari.abdallah87@gmail.com, poniriskan@gmail.com, ayuesteka82@gmail.com, \\ maryantoyanto1974@gmail.com
}

\begin{abstract}
Abstrak
Industri Tauge atau kecambah dalam skala rumah tangga di Kota Sungai Penuh khususnya Pelayang Raya di Desa Sungai Jernih Dusun Batu Panjang Kecamatan Pondok Tinggi telah dilakukan sejak lama, industri ini tetap ada seiring dengan kebutuhan masyarakat. Tauge yang digunakan sebagai sayur dan dipercaya memiliki gizi yang tinggi. Disamping itu tuntutan pola makan yang sehat dan bertambahnya menu kuliner yang menyertakan tauge berarti konsumsi tauge juga membantu memenuhi kecukupan protein nabati. Tujuan dan sasaran khusus yang dicapai dalam program Program Kemitraan Masyarakat Stimulus (PKMS) ini adalah 1) Peningkatan ketrampilan pengembangan usaha dari sisi teknologi tepat guna. 2) Membantu peningkatan kemampuan proses produksi yang memenuhi standard produktifitas dan kenyamanan usaha. 3) Membantu peningkatan pemahaman mengenai laporan keuangan dan akuntansi. Target dalam kegiatan PKMS ini adalah Usaha Toge Bapak Sumaryo. Metode yang digunakan dalam kegiatan ini adalah membuat alat penyemprot otomatis dan kebersihan tempat produksi tauge. Memberikan pelatihan dan pemahaman mengenai laporan keuangan dan akuntansi. Selanjutnya, Mitra Sasaran diberikan pelatihan bagaimana penggunaan mesin siram otomatis tauge serta pelatihan pembuatan laporan keuangan dan akuntansi. Adapun alat ini berfungi sebagai pengontrol penyiraman secara otomatis pada saat dilaksanakannya penyirman pada toge.
\end{abstract}

Kata Kunci : Kualitas Produk, Pelatihan Laporan Keuangan, Teknologi Kreatif

\begin{abstract}
The Stimulus Community Partnership Program (PKMS) is Mr. Saepudin's "Sari Ikan Cracker Business". His business produces cracker snacks with various flavors but the most famous is crackers with fish flavor. Based on the results of field visits, interviews, and observations of partners, it can be identified several priority problems faced by partners including: a) For the production process still using traditional tools, the limited tools used so that hinder the production process. This is shown by: in working on the cracker production process which is still simple and still manual, the number of production of crackers is limited. Provide financial management and accounting training. Based on the priority issues that must be addressed, several solutions that the PKMS team offers to partners are: Production sector by providing the transfer of Appropriate Technology (TTG) in the production process in the form of Blower machines that assist in the frying process and Gerombong, Packaging by providing packaging machines and tools crackers so that the packaging of crackers becomes more hygienic, the Financial Sector by providing training and assistance in making Financial Reports. The results of this PKMS output target are: Increasing the productivity of partners by using cracker production machines, increasing the tidiness and hygiene of cracker packaging and increasing the knowledge of partners in making financial reports.
\end{abstract}

Keywords: product quality, increased production, Appropriate Technology (TTG), financial reporting trainin. 


\section{PENDAHULUAN}

Usaha Mikro, Kecil dan Menengah (UMKM) memiliki peran penting dalam laju ekonomi Indonesia terutama dalam penciptaan lapangan kerja dan pemberdayaan rumah tangga yang mendukung pendapatan rumah tangga. Keberadaan UMKM diharapkan mampu memacu perekonomian di tengah perlambatan ekonomi yang terjadi saat ini (Purwana dkk, 2017). Usaha Mikro Kecil Menengah (UMKM) di Indonesia merupakan salah satu soko guru perekonomian Indonesia selain koperasi. Hal ini dapat terlihat dari bukti nyata bahwa sebagian besar UMKM di Indonesia tidak menghadapi krisis di tengah-tengah krisis global pada tahun 2008 lalu (Fatwitawati, 2018). Berbagai masalah pokok yang dihadapi UMKM dengan menggolongkannya menjadi masalah internal dan masalah eksternal (Purwanti,2018). Perkembangan Salah satu Mitra dalam pelaksanaan Program Kemitraan Masyarakat Stimulus (PKMS) adalah Usaha Mikro, Kecil dan Menengah (UMKM) Touge.

Bisnis kecambah (tauge) di Kota Sungai Penuh khususnya di Pondok Tinggi mulai berkembang pesat seiring dengan kebutuhan pola makan yang sehat. Tauge tersebut dibuat dan dipasarkan secara tradisional di pasar Tanjung Bajure Sungai Penuh serta di Pasar Tradisional di Tingkat Kecamatan atau yang disebut Balai. Prospek kecambah ini sangat menjanjikan terutama dari segi citra rasa khas menu makanan tersebut dan harga yang sangat terjangkau bagi konsumen karena menjadi pelengkap menu makanan.

Di Desa Sungai jernih Kecamatan Pondok Tinggi Kota Sungai Penuh terdapat kelompok pembuat tauge, dimana usaha pembuatan tauge oleh warga ini belum dilaksanakan secara profesional, tetapi masih bersifat tradisional. Salah satunya adalah Produksi Touge Sunaryono. Bapak Sunaryono merupakan mitra di kegiatan Program Kemitraan Masyarakat Stimulus (PKMS) ini.

Umumnya produk khas tauge diproduksi oleh mitra per hari berkisar 200-400 kg tauge, sedangkan permintaan untuk Masyarakat dan konsumen masih cukup tinggi. Produksi Touge Sunaryono memiliki 3 orang pekerja yaitu: Poniah, Maryati dan Arif, Dimana pekerja tersebut sebagian mengandalkan sumber pendapatan utamanya berasal dari usaha pembuatan tauge yang menerima pesanan dan melayani warung dan toko yang dijual ke pasar wilayah Kota Sungai Penuh dan Kabupaten Kerinci. Dalam proses pembuatan tauge sebagian besar pembuat masih menggunakan teknologi atau alat sederhana serta masih mengandalkan cara-cara tradisional dengan tenaga manual dan jumlahnya yang terbatas. Saat adanya permintaan yang tinggi untuk memenuhi kebutuhan agen-agen penjualan di Pasar Sungai Penuh dan Kabupaten Kerinci dan juga memenuhi atau melayani pesanan tauge dari tempat lain, sehingga dalam upaya untuk meningkatkan target penjualan yang optimal serta efisien dalam penggunaan waktu dan tenaga selama pembuatan tauge tersebut, maka jika ditangani secara profesional dengan menggunakan alat proses yang lebih baik dalam pembuatan tauge diharapkan akan meningkatkan kualitas dan kuantitas produksi tauge. 
Tauge banyak mengandung senyawa fitokimiawi yang berkhasiat. Protein tauge lebih tinggi 10 persen dibandingkan dengan kandungan protein dalam biji aslinya, hal ini disebabkan selama proses menjadi kecambah terjadi pembentukan asam-asam amino esensial yang merupakan penyusun protein. Tauge baik dari kacang kedelai, kacang hijau mapun kacang tunggak mengandung vitamin c sebanyak $15 \mathrm{mg}$ setiap 100 gram. Touge juga merupakan sumber vitamin e yang sangat potensial dengan kandungan $662 \mathrm{mg}$ setiap 100 gram. Manfaat tauge antara lain adalah dapat mencegah kanker, mencegah serangan jantung dan stroke, mencegah osteoporosis, membangkitkan sistem kekebalan tubuh (Mahandika dkk, 2020). Kandungan gizi yang terdapat di tauge adalah vitamin A, B Kompleks, C, E, serta mineral seperti kalsium, zat besi, magnesium, kalium, serat, folat, asam amino dan protein. Konsumsi tauge memiliki sifat alkali atau basa yang membuatnya efektif untuk membantu meredam kenaikan asam lambung dalam pencernaan. Kandungan seratnya yang tinggi sangat penting membantu melancarkan fungsi pencernaan (Purwanti dkk, 2019). Vitamin yang ditemukan dalam tauge adalah vitamin C, thiamin ,riboflavin, niasin, asam pantothenik, vitamin B6, folat, kolin, B- karoten, vitamin A, vitamin E (a- tokoferol), dan vitamin K. Mineral yang ditemukan dalam tauge adalah kalsium $(\mathrm{Ca})$, besi $(\mathrm{Fe})$, magnesium $(\mathrm{Mg})$, fosfor $(\mathrm{P})$, potasium $(\mathrm{K})$, sodium $(\mathrm{Na})$, zinc $(\mathrm{Zn})$, tembaga $(\mathrm{Cu})$, mangan $(\mathrm{Mn})$, dan selenium (Se). Asam amino esensial yang terkandung dalam tauge, antara lain: triptofan, treonin, fenilalanin, metionin, lisin, leusin, isoleusin, dan valin (Hairunnisa dkk, 2016).

Sebagai salah satu tanaman pangan utama, terutama di daerah Asia, tauge (Vigna radiata L.) menawarkan banyak manfaat dan keuntungan bagi yang mampu memproduksinya dengan benar. Memproduksi tauge tersebut sangat membantu baik dari aspek konsumsi maupun bisnis. Namun, ketidakefektifan dalam proses produksi sering menghasilkan produk tauge yang rusak (Merpaung, 2021). Kacang hijau (Vigna radiata L.) merupakan salah satu komoditas tanaman kacang-kacangan yang banyak dimakan rakyat Indonesia, seperti: bubur kacang hijau, pia, dan lain-lain. Tanaman ini mengandung zat-zat gizi, antara lain amylum, protein, besi, kalsium, lemak, vitamin (Soedirman, 2013).

Nurcahyono telah membuat suatu alat budidaya kecambah berbasis Mikrokontroler ATMEGA16. Adapun alat ini berfungi sebagai pengontrol pada saat penanaman kecambah, sebagai pembaca suhu dan kelembaban adalah sensor SHT11, dan dilengkapi pemanas serta kipas untuk membantu menstabilkan suhu yang telah ditetapkan (Nur cahyono dkk, 2016).

Pada pengabdian yang dilaksanakan oleh Nur pada Madrasah Aliyah MDIA Bontoala, mesin penanam tauge yang dibuat menggunakan wadah pelastik berwarna hitam dan tertutup. Pada bagian penutup wadah diletakkan selang dengan diameter $7 \mathrm{~mm}$ dengan nosel kabut sebanyak 4 buah, air diletakkan dalam wadah kurang lebih 10 liter, pompa spray akan mendorong air ke selang distrisbusi untuk melakukan penyiram, hasil penyiraman akan ditampung diwadah dan dapat digunakan untuk menyiram tanaman tauge sebanyak 4 kali. Untuk mengontrol waktu penyiraman digunakan timer digital yang bekerja sesuai waktu yang telah di set pada timer tersebut (Nur dkk,2018). 
Kendala mengeni produktivitas dari proses produksi yang dilakukan adalah kurang rapi dan kurangnya keselamatan dari proses produksi dari Touge. Aspek peralatan produksi merupakan salah satu asset bagi para pelaku UMKM baik itu yang tradisional maupun yang sudah modern atau menggunakan teknologi canggih. Peralatan produksi dapat berupa barang bergerak maupun barang tak bergerak, tanpa peralatan produksi yang memadai akan sulit bagi pelaku UMKM untuk dapat tumbuh berkembang dalam menjalankan usahanya.

Berdasarkan hasil kunjungan ke lapangan, wawancara dan pengamatan terhadap Mitra, dapat diidentifikasikan beberapa permasalahan prioritas yang dihadapi Mitra, diantaranya Keberadaan pengrajin tauge menjadikan usahanya sebagai mata pencaharian yang berbasis usaha mikro dengan mempunyai spesifikasi unggulan yang dapat diberdayakan potensi ekonominya sehingga masyarakat dapat terdorong untuk semakin mengembangkan produktifitas usahanya. Disamping itu kondisi pengrajin yang masih tradisional mengakibatkan kurang maksimalnya produksi tauge.

Berdasarkan profil mitra tersebut, maka permasalahan yang dihadapi adalah : 1) Kurang adanya inovasi peralatan TTG dalam proses pembuatan tauge, khususnya terkendala dalam hal penyiraman tauge. 2) Kondisi tempat tauge pasca pembuatan yang masih sederhana, sehingga perlu peningkatan pemahaman proses tentang kebersihan dalam pencucian biji kacang hijau agar kualitas produk menjadi lebih baik.

\section{METODE PELAKSANAAN}

\section{Prosedur Kerja}

Model yang ditawarkan untuk mengatasi persoalan produksi tauge dan manajemen bagi mitra adalah : 1) Membantu menyiapkan pendampingan untuk meningkatkan keahlian dan ketrampilan dalam tata kelola produksi sehingga produktifitasnya meningkat. 2) Memberi dukungan bantuan peralatan dan perbaikan tempat produksi yang lebih memadai guna meningkatkan kualitas produk tauge.

\section{Mekanisme Pelaksanaan}

Rencana kegiatan yang menunjukan langkah-langkah solusi atas persoalan pada gambar di atas yaitu:

\section{a) Tahap Analisis Situasi dan Kondisi Mitra}

Pada tahap ini tim pelaksana melalukan survey, pengumpulan data dan identifikasi masalah mitra, serta melakukan Focus Group Discussion (FGD) dengan mitra untuk jadwal pelaksanaan kegiatan PKMS yang akan dijalankan.

\section{b) Tahap Persiapan dan Pembuatan TTG}


Pada tahapan ini dijalankan dengan dua tahapan yakni pada melaksanakan kegiatan dan pembuatan alat penyiraman Otomotis tauge serta Pembuatan tempat produksi.

\section{c) Tahap Pelatihan}

Pada tahap ini Tim pelaksana akan memulai kegiatan pelatihan sesuai dengan jadwal yang sudah ditentukan dan disepakati bersama dengan mitra.

\section{HASIL DAN PEMBAHASAN}

Gambaran usaha mitra sebelum adanya dukungan peralatan yang dilakukan oleh tim PKM, antara lain :

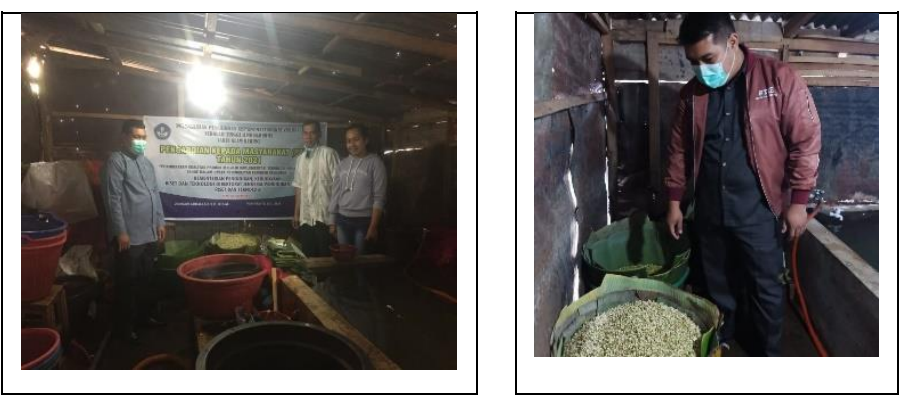

Gambar 1. Keadaan Sebelum Inovasi Kepada Mitra Pengabdian

Dalam produksi tauge, antara masalah yang dihadapi adalah ketidak seragaman waktu penyiraman, volume air siraman yang tidak konsisten, kegagalan penyiraman pada waktu malam. Dalam proses Produksi Touge Sunaryono untuk penyiraman yang masih manual dengan hanya menggunakan slang air biasa, sehingga hal ini membuat proses produksi yang menjadi lambat dan membutuhkan waktu serta tenaga untuk menyiram touge. Serta dinding dari tempat proses produksi toge yang hanya disekat dengan seng. Sehingga Hasil tauge kurang berkualitas yaitu tauge yang halus, akar panjang, akar pendek, kulit atau testa terlekat pada tauge dan tidak tahan disimpan lama. Kualitas tauge yang dikeluarkan secara manual berubah karena suhu tidak menentu. Suhu dipengaruhi oleh frekuensi siraman dan kuantitas air. Untuk memfasilitasi kerja menyiram tauge serta meningkatkan hasil dan kualitas tauge, maka oleh Tim Pengabdian yang dipimpin oleh Zachary Abdallah, S.E., M.S.Ak. telah merekayasa Set Produksi penyiraman Tauge Otomatis yang memungkinkan siraman dilakukan secara langsung tanpa menggunakan slang air, sehingga lebih menghemat energi dan proses produksi. 

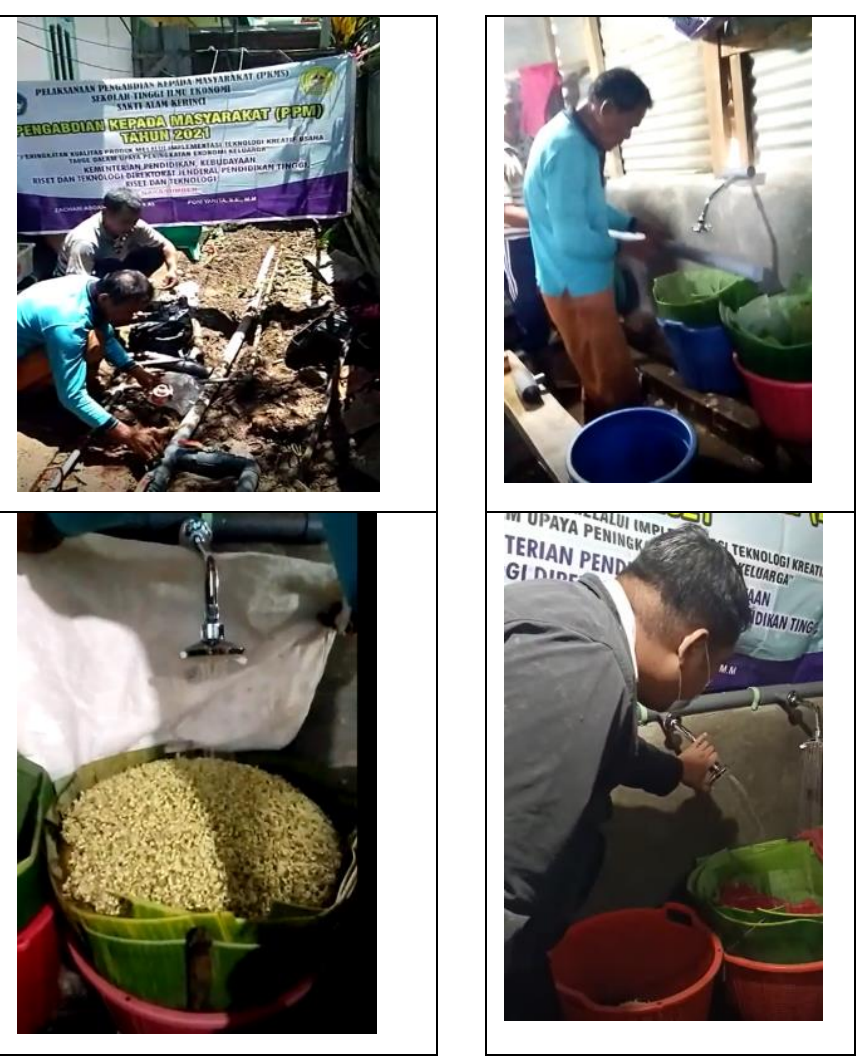

Gambar 2. Keadaan Sesudah Inovasi Kepada Mitra Pengabdian

Saat ini mitra pembuat tauge rata-rata mampu meningkatkan produksi hingga $25 \%$ per bulan dari produksi sebelum implementasi alat penyiraman otomatis dan juga advokasi faktor kebersihan saat pencucian biji kacang hijau sangat menentukan keberhasilan perkecambahan kacang hijau, sehingga kualitas tauge menjadi lebih baik terbukti adanya prosentase tauge yang busuk atau yang berwarna coklat menjadi sangat berkurang. Dengan demikian peningkatan produktifitas usaha mitra lebih disebabkan oleh implementasi alat penyiraman otomatis yang berdampak pada lebih meratanya penyiraman dan kelembaban yang ideal bagi proses perkecambahan, juga meringankan beban penyiraman karena jika dengan cara manual dengan menggunakan slang pada setiap 3 jam sekali diperlukan tindakan penyiraman selama 15 menit. Demikian juga advokasi faktor kebersihan saat pencucian biji kacang hijau sangat mempengaruhi kualitas dan keberhasilan perkecambahan tauge karena resiko tauge yang busuk atau berwarna coklat menjadi sangat rendah. Sehingga Hasil tauge kurang berkualitas yaitu tauge yang halus, akar panjang, akar. 


\section{KESIMPULAN}

Berdasarkan hasil kegiatan Program Kemitraan Masyarakat Stimulus (PKMS) pada mitra dapat disimpulkan bahwa : 1) Hasil kegiatan Program Kemitraan Masyarakat Stimulus (PKMS) menunjukkan bahwa pendapatan mitra meningkat $20 \%$ dari sebelum inovasi berarti usaha mitra menguntungkan dan dengan makin meningkatkan produktivitas pembuat tauge dapat berdampak pada naiknya pendapatan mitra, sekaligus kondisi ini ikut berdampak pada meningkatnya kesejahteraan hidup keluarga. 2) Meningkatkan produktivitas dari proses pengolahan Touge dari proses penyiraman dan higienitas dari tempat produksi.

\section{Saran}

Maka disarankan seyogyanya ada perhatian yang khusus dari pemerintah kota maupun lembaga lain baik dari pemerintah maupun swasta yang ditujukkan kepada UMKM di Kota Sungai Penuh untuk dapat memberikan pelatihan dan wadah yang dapat mendukung pengembangan kegiatan seperti dengan adanya penambahan dari penyaluran modal. Karena bagaimanapun mereka merupakan penggerak perekonomian negara dan mempunyai peran penting terhadap pertumbuhan ekonomi Indonesia pada umumnya dan peningkatan pendapatan keluarga pada khususnya.

\section{UCAPAN TERIMA KASIH}

Penulis mengucapkan terima kasih kepada Kementerian Pendidikan, Kebudayaan Riset, Dan Teknologi Direktorat Jenderal Pendidikan Tinggi, Riset, Dan Teknologi yang telah memberi dukungan moral dan dana terhadap program pengabdian masyarakat ini ini. 


\section{DAFTAR PUSTAKA}

D. Purwana, R. Rahmi, and S. Aditya, "Pemanfaatan Digital Marketing Bagi Usaha Mikro, Kecil, Dan Menengah (UMKM) Di Kelurahan Malaka Sari, Duren Sawit,” J. Pemberdaya. Masy. Madani, vol. 1, no. 1, pp. 1-17, 2017, doi: 10.21009/jpmm.001.1.01.

R. Fatwitawati, "Pengelolaan Keuangan Bagi Usaha Mikro Kecil Menengah (UMKM) Di Kelurahan Airputih Kecamatan Tampan Kota Pekanbaru," Sembadha, p. 32, 2018.

E. Purwanti, "Analisis Pengetahuan Laporan Keuangan Pada Umkm Industri Konveksi Di Salatiga," Among Makarti, vol. 10, no. 2, 2018, doi: 10.52353/ama.v10i2.152.

T. G. R. Mahandika, K. Kusnila, A. Aisyah, W. Warjito, and H. H. Pranata, "Brownies Tauge Coklat," Wasana Nyata, vol. 3, no. 2, pp. 135-143, 2020, doi: 10.36587/wasananyata.v3i2.526.

S. Purwanti, N. Nurlina, and B. Gunawan, "Implementasi Teknologi Kreatif Dalam Mewujudkan Umkm Produktif Melalui Program Kemitraan Masyarakat (Pkm) (Kelurahan Kertajaya, Kecamatan Gubeng Kota Surabaya)," JPM17 J. Pengabdi. Masy., vol. 4, no. 1, pp. 49-54, 2019, doi: 10.30996/jpm17.v4i1.1996.

O. Hairunnisa, E. Sulistyowati, and D. Suherman, "Pemberian Kecambah Kacang Hijau (Tauge) terhadap Kualitas Fisik dan Uji Organoleptik Bakso Ayam,” J. Sain Peternak. Indones., vol. 11, no. 1, pp. 39-47, 2016, doi: 10.31186/jspi.id.11.1.39-47.

D. Marpaung, "Community Empowerment through Mung Bean Sprouts Production Training TeknoKreatif: Jurnal Pengabdian kepada Masyarakat Community Empowerment through Mung Bean Sprouts Production Training Program," TeknoKreatif J. Pengabdi. Kpd. Masy., vol. 1, no. August, pp. 7-14, 2021.

U. J. Soedirman, "Proposal Program Kreativitas Mahasiswa Pengaruh Spektrum Warna Terhadap Perkembangan Vegetatif dan Generatif Kacang Hijau (,” 2013.

E. Nurcahyo, N. P. Agustini, B. P. Hartono, and T. Herbasuki, “Alat Pengolah Kecambah Kacang Hijau Berbasis Mikrokontroler Diterapkan Pada Petani," in SEMINAR NASIONAL INOVASI DAN APLIKASI TEKNOLOGI DI INDUSTRI (SENIATI), 2016, pp. 152-158.

D. Nur, K. Kasim, and M. F. Raharjo, "Pelatihan Pembuatan Tauge Dengan Sistem Penyiraman Otomatis Di Pondok Pesantren Mdia Bontoala Makassar,” Semin. Nas. Has. ..., vol. 2018, pp. 439-443, 2019, [Online]. Available: http://jurnal.poliupg.ac.id/index.php/snp2m/article/download/1468/1366. 